\title{
The Italian Intelligence from the Pre-Unification Period to the First World War*
}

\author{
Antonella Colonna Vilasi \\ Centro studi Uni, Rome, Italy \\ Email: mavil@tiscali.it
}

How to cite this paper: Colonna Vilasi, A. (2018). The Italian Intelligence from the Pre-Unification Period to the First World War. Open Journal of Political Science, 8 , 57-67.

https://doi.org/10.4236/ojps.2018.81005

Received: December 25, 2017

Accepted: January 21, 2018

Published: January 24, 2018

Copyright $\odot 2018$ by author and Scientific Research Publishing Inc. This work is licensed under the Creative Commons Attribution-NonCommercial International License (CC BY-NC 4.0).

http://creativecommons.org/licenses/by-nc/4.0/

\begin{abstract}
In the newly formed Kingdom of Italy the first Intelligence operations were focused on the public order protection and the citizens' security. This analytical, theory-building article examines the pre-existing core of the Italian Intelligence from the pre-unitarian Italian States to the First World War from a different perspective, evaluating the culturally transmitted factors that influence politico-military elites, security communities, and decision-makers.
\end{abstract}

\section{Keywords}

Intelligence, Military Intelligence, Security, Italian Intelligence

\section{Introduction}

The notions of security and stability are central to our contemporary society. Social and State security is a major pillar if not a prerequisite of a democratic system.

The ability or inability to provide security is central to democratic Nations.

In the near future the Intelligence agencies and governments will increasingly depend on those warning mechanisms which can promptly respond to an even more and complicated task, the prevention of security.

The following article will evolve around the notions of the Italian Intelligence and the application of strategic warning, Intelligence, policy failures, and strategic foresight referred to the Italian Intelligence before the 1861 unification process and to the First World War.

*Pioneer in Intelligence Studies in Italy, during the last 20 years the author's research interests focused on Intelligence, the relation with the Political Science and the Intelligence Cycle. With more than 70 books published on the topics; among them: The Intelligence Cycle, The History of M16, The History of the CIA, The History of the Italian Secret Services, The History of the Entity, The History of Mossad, and The History of the STASI. 


\section{Research Questions}

With reference to this research, the first question posed is: how was Intelligence capable of addressing the new challenges posed by a united country?

Second question: what were the new capabilities, know-how and analysis tools that Intelligence needed in such a new and complex reality (a Nation made up of different states, with different laws, coins, etc.) as to require a new approach?

\section{Research Methods}

This study uses a three-step methodological approach: data collection, coding and analysis, using qualitative techniques.

In particular using a three stage process includes:

- a discovery phase of data collection;

- a coding phase using some of the analytical techniques and proposed methodologies as filters;

- an analysis phase using argumentation analysis and Intelligence analysis.

The article offers a number of original contributions to the scientific literature.

First, it re-examines the sources and the theory-building and proposes alternatives to the referable scientific literature accepted and proposed by the majority of scholars.

Secondly, it strengthens the holistic interrelations in terms of consistency between disciplines such as Intelligence studies, history, sociology, political geography, and political science.

The article's mixed methods approach advances a research agenda that addresses potential analytic and cognitive biases that can affect the "at a distance" examination from a pre-unitarian Italian Intelligence up to the First World War.

A new understanding will emerge on how we can contribute to analysing and understanding the previous and future core of the Italian Intelligence system.

Thirdly, the proposed mixed methods generate an agenda for possible future studies and researches.

The documents used refer to Open Source documents, archives, publications, and reliable secondary sources.

The article relies on selected primary sources where possible, and a mixed methods, evaluative approach to secondary sources. The crucial gaps in some of the comparative sources are crossed over with newly available sources.

The limitation of this research is due to the fact that it should be treated with an entire volume, and not only with a brief article.

\section{Literature Review}

Academic studies, apart from the bibliography proposed in the article, refer mainly to the Italian studies of the sector.

There is not much Literature Review on the topic.

Not to mention Colonna Vilasi (2013). Storia dei servizi segreti italiani, and 
Pasqualini (2006). Carte Segrete delP Intelligence Italiana. 1861-1918, we can state that Giuseppe De Lutiis (1991). Storia dei servizi segreti in Italia, is undoubtly a milestone in Italian Intelligence studies.

As far as the Information collection here studied is concerned, it derived from covert sources (from the Defense or other Intelligence agencies), or from Open Source documents like: archives, publications, radio, TV, newspapers, scientific dissertations, and secondary sources as well.

This analytical, theory-building article examines the pre-existing core of an Italian Intelligence organization from the pre-unitarian Italian States to the First World War from a different perspective, evaluating the culturally transmitted factors that influence politico-military elites, security communities, and decisionmakers.

The main argument is that a structured and composed Intelligence organization was already active in each and every single State (Naples and Sicily, Parma, Piedmont, etc.).

We cannot thus state that only after the formation of a united State, in 1861, an Intelligence Agency was set up.

This article can thus be a contribution to the gap in the literature of the field, and its relevance is due to the fact that at the moment the evolution of the Italian Intelligence from the pre-unitarian Italian State to the First World War is not much studied.

\section{From the Pre-Unitarian States to the Unification (1861)}

Before describing the organization and the development of the Italian Intelligence in the second half of the nineteenth century, from the foundation of a unified State until the First World War, it is appropriate to illustrate the security management and the information exchange in the pre-unification period.

In the newly formed Kingdom of Italy the first Intelligence operations were focused on the public order protection and the citizens' security (Viviani, 1985), and were based upon an already existing military and civilian organization that employed a discontinuous number of informers and agents.

They operated secretly or overtly with no respect of the citizens' rights.

In wartime the Intelligence Units were not yet included in the corps and their mission consisted in: land reconnaissance, the enemy's operations spying, and the interrogation of citizens and prisoners.

After the revolutionary coups in the first half of the century, the pre-unitarian States stepped up the security apparatus, Intelligence and information sharing.

As in other fields, the Kingdom of Sardinia was a forerunner in security matters and public order.

In the early nineteenth century's Grand Duchy of Tuscany, both the "Buon Governo" and the police (whose commander was the president of the "Buon Governo") had the task of protecting the peoples' security.

Under the orders of a hearing officer, the military police tasks were assigned 
to a sheriff.

In the Kingdom of Lombardo-Veneto, Milan and Venice were the seats of the Police Directorate and lieutenants, heading each province's delegates and commissioners.

The commissioners were entrusted of a periodical report to the hierarchy in reference with the operational tasks of information gathering, while the State Department, in Wien, could be informed if necessary from the various Departments.

In 1849 the "Gendarmi" corps was established for the control of public and private security.

The Border Guards were encharged almost exclusively of smuggling and tax protection, while in 1840 the Guardia di Finanza corps (created in 1774) became an armed body.

As regards the Vatican State, the police director was the Cardinal Secretary of State, that directed the Cardinals of each provincial police. The Police Guards, the Papal Gendarmes, the Urban Guards, the Civic Guards and the volunteers Corps were in action in the provincial districts where the police was ruled by secular representants, while there is no information about military Intelligence.

The Guardia di Finanza had the task of gathering and transmitting information to other corps with the result of an overlap of tasks.

In 1849 the Police Guards were abolished, and the police tasks were transferred to the Ministry of War, with the creation of the Directorate of Public Security and Police Public Security.

In the Duchy of Parma, a General Police Directorate was set up for public security. From 1859 on it melted with the Carabinieri corps, and was further accused of the 1831 riots, and put on trial for the incidents.

In 1850 the police tasks, often malfunctioning, passed to the gendarmerie and to the military commands and in 1851 Charles III set up for the first time the preparation of dossiers from governmental employees and professionals.

In the Duchy of Modena the security management was entrusted to a civilian militia as for the countryside security, and to volunteers for public security.

In 1831 a disinformation operation was mastered on behalf of Duke Ferdinand IV against the population and their revolutionary projects.

Fake lodge accommodations were given to let the people believe in the imminent arrival of the Austrian troops (Colonna Vilasi, 2013).

In the Kingdom of the Two Sicilies, the police was the most powerful institution; at the top level were the King Secretariat (with a powerful Intelligence service) and the General Police Directorate, depending from provincial directorates, commissioners and inspectors.

Undercover Guards were operating with the task of informing the provincial intendants.

In 1827 , due to the limits in tackling the revolutionary movement, it was created the Royal Gendarmerie and the police veterans had the most delicate tasks. 
In 1833, King Ferdinand II created the Domestic Security Guard, headed by wealthy citizens with proven faith.

After the Palermo's riots of 1848, it was established the Public Security Guard, in which melted the gendarmerie and the police.

The captain of gendarmerie Salvatore Maniscalco, director of police, and his secretary Favalor established an efficient Intelligence service, that monitored Garibaldi and the "Spedizione dei Mille" of 1860 (nevertheless an unheeded warning).

In 1851, a Statistical commission was created (similar to that of the Kingdom of Savoy), the core of an information service. Finally, in the military field, the War Deposit was established for collecting information.

With the Royal Patents of 1814, the King of Sardinia Vittorio Emanuele of Savoy created the Buon Governo's General Directorate and the Royal Carabinieri Corps.

The Royal Carabinieri, although a section of the Army, had no military tasks, and their commander was called the "first president of the Buon Governo".

The Buon Governo was replaced in 1816 by the new Ministry of Police with the task of protecting public security and public order.

After the 1821 uprising in Piedmont an information service was implemented.

In 1821-1822 the Royal Patent settled the merging of the Ministry of Police with the Secretary of State for Foreign Affairs, with military and civilian commanders.

The guidelines for the police functions, including military police and counterIntelligence (in time of war: camp control, observation of spies and suspects; in time of peace: control on the militaries on leave and license, arrest of resisting persons, detecting deserters from foreign armies) merged into a new regulation, which did not include, however, espionage.

In 1821 a civil service apparatus was constituted, designed by the first Secretary of State, Roget de Cholex, and approved by the King Carlo Felice.

A trusted network of people under coverage (and in conjunction with the reports of the police authorities) had the task of transmitting information to the Secretary of State on the realm, with particular attention to secret societies, to foreign suspects and indicted.

Led by a police Chief Officer, was named "Affari di Polizia" or "Seventh Office". Initially it was ruled by the Marquis Giovanni Raggi and consisted of one hundred employees, divided into three core divisions, plus other peripherals. But also governors and military commanders were included in the top staff so as to create a confusion of responsibilities.

In 1841, the Office was transformed into the "Gabinetto particolare di Polizia".

The military information service developed in the years 1816-1848.

The Kingdom of Sardinia General Staff was created in 1816 with the aim of collecting information for the troops and operations during wartime.

The Savoy Intelligence service can be dated to the period after the First War of 
Independence and afterwards was absorbed by the new Italian State, from 1861 onwards, respectively, by the military Intelligence and the Foreign Affairs Intelligence.

In April 1855, the "Breve istruzione sul servizio degli Ufficiali del Corpo Reale di SM in caso di guerra" was drafted, and a special mission section and an Intelligence one were created. The first had tactical tasks, the second strategical.

In 1856 in Turin the forerunner of the Italian military Intelligence, headed by the Major Giuseppe Govone, was named "Intelligence Office" (known further as the "General Staff (SM) Information Office").

The year 1854 can be considered the birth of the Foreign Affairs Intelligence, with an international policy conducted from the Kingdom of Savoy and Count Camillo Benso di Cavour.

In 1836 Count Camillo Benso di Cavour was called by King Carlo Alberto, along with Colonel Alfonso La Marmora, to attend the Great Statistics Board, a sort of central information gathering section.

Cavour was the head of the civil service from 1856 to 1860, although he had at the same time institutional roles, fostering the participation of a united Italy into the international scenario.

Among the most famous spies we can name: Virginia Oldoini, Countess of Castiglione, Daniele Manin (who created the Italian National Society, an Intelligence structure made of 4000 men), Giuseppe La Farina and Costantino Nigra, ambassador at the court of Napoleon III.

The Cavour strategy had a dual purpose: subversive against the Austro-Hungarian Empire and repressive against the secret societies. The diplomatic network was very important for the Unification of Italy: financed part of the French press in favor of his policy, and at the same time supplied the weapons to the Hungarian fighters.

Secret agents were spread to several Italian States to sponsor the unification, in view of the Italian kingdom that was to be created after the 1859's campaigns.

During the independence campaigns of 1859 the Lieutenant-Colonel Giuseppe Govone (although disagreeing with many General Staff officers and commanders), managed to head brilliantly the Information Service (Servizio Informazioni) preparing reports, collecting information via couriers and stealing the Austrian correspondence.

Characterized from a lack of organization and coordination, nevertheless managed successfully in the information collection for the National defense.

The Police was reorganized and divided in a political police or "polizia alta" and a "polizia bassa", for public security.

In 1861, at the Home Office, the Intelligence Section depended from a political office (Prime Minister's Cabinet), and from a public security office ( $2^{\text {nd }} P u b-$ lic Security Division).

The latter had information tasks in common crimes, and depended from a Directorate of Public Security and was composed of the Public Security Guards. 
The Intelligence service was subsequently subject to several changes of name, from "Public Security Affairs" passed to "Police $3^{\text {rd }}$ Division" (1868) and "Political Bureau at the Directorate of Public Security" (1881). In 1890 the Public Security officers were named officially "city guards".

The so-called "polizia alta" was first named "1st Division General Affairs's Bureau" (1859) and then "Secret Affairs Cabinet" (Ufficio Affari Riservati del Gabinetto-1900).

In 1861, the Home Office Intelligence (political police Section), was misused by the Prime Minister Giovanni Ricasoli to influence elections and control the press.

In 1862, an operation conducted by General Sanfront, former head of Cavour's Intelligence, stopped the Garibaldi's expedition to Austria (Sarnico-Bergamo).

A Military School for the Polish refugees in Cuneo was also created.

Costantino Nigra, ambassador to Paris, before the Third War of Independence (1866), set up an efficient information system about the political and military situation in France.

In 1867, the joint action of the Intelligence, Home Office and Foreign Affairs, focused on Garibaldi's attempts to conquer Rome and tried to provoke an insurrection that would give a hand to Garibaldi's expedition.

In 1874, the Intelligence stopped an insurrection plot in Bologna by the anarchists Andrea Costa and Mikhail Bakunin, and arrested in Florence Anna Kuliscioff, Andrea Costa's lover and assistant.

In 1876 the Home Office information apparatus had a significant expansion and a consequent reorganization during the Left Government.

The new Home Office Minister, Minister Giovanni Nicotera, aware of the importance of an Intelligence apparatus, without informing the Parliament, strengthened its structure.

Several deviation episodes occured: agents infiltrated to gather evidence against Francesco Crispi, illegal funds administration to bribe the press, telegraph and mail tapping.

The Roman Bank affair, one of the six institutions qualified to issue money, and linked to some Left fringes was the first scandal of the "civil service" (in opposition with the military one) and took place in 1892-1894, during Giovanni Giolitti's premiership.

The bank governor, after the arrest, confessed the money paid to Crispi and Giolitti.

The prime minister was forced to resign at the end of 1893 , and was replaced by Crispi.

All the accused were conducted to jail, but the judges denounced the disappearance of the documents essential to prove them guilty.

In 1898, the new Prime Minister Luigi Pelloux gave to the Intelligence apparatus full autonomy in the protection of National security and in coping with the frequent riots and anti-militarist propaganda. 
In the Royal Carabinieri Corps, so named from 1861, merged the pre-unification State's security structure and the information services.

The fourteen legions in which the corps was organized were distributed throughout the territory, especially in the countryside.

In 1863, at the army General Staff was created the "I" Office, a Central Information Office, reflecting the Govone Intelligence structure.

Edoardo Driquet, a colonel of Hungarian origin, was in charge of the service. After three years, however, was forced to resign, following the defeat of the 1866's military campaigns.

In 1861 the Ministry of the Navy was separated from the War Ministry, and a new information service was created.

The information quest, however, was always up to the local commander and each single unit updated the war situation: via the interrogation of deserters and civilians, observation of enemy activities, border surveillance.

In 1875 , the counter-Intelligence activities were attributed to the Carabinieri corps (military police) and had the task of informing the General commands.

The n. 968, 1882 Decree, established the position of Army (SME), Chief of Staff, that referred to the Minister of War about the troops management.

In 1889 the SMM commander position was established. In 1892 the "Regolamento di servizio di guerra" issued by the Minister of War, specified that the SME Commander, had the task of directing the local information Chief of Staff Unit.

Both the SME commander and the SMM one depended from the General Staff "I" Office.

According to some General Staff documents kept in the SIM archives the "I" Office was hidden until 1897 and was headed by Colonel Felice de Chaurand de Saint Eustache (Pasqualini, 2006).

His successor, Colonel Vincenzo Garoni, in only three years created an efficient organization, bought the first telegraphic ciphers, issued rules for the informants correspondence, settled the officers along the border and secured a good financial budget.

Thus during the first forty years the Italian Intelligence was constituted by various Intelligence services, schematically summarized in:

- the Royal Carabinieri Corps Intelligence, the most secret of all, dedicated to the collection of information especially in the countryside, linked to the royal family;

- the Guardia di Finanza Intelligence, with institutional purposes;

- the Ministry of War and the Ministry of the Navy Intelligence, formed by a network of informers, military attaches and officers abroad;

- the "I" General Staff Office (Army);

- the Home Office Intelligence, divided into Polizia alta e bassa;

- the King and the Prime Minister Intelligence, one for each of the two authorities, autonomous, limited, free from the military supervision; 
- the Foreign Affairs Intelligence, spread in diplomatic representations, and based on informants living abroad (the "patriots ").

After the war in Libya (1911-1912) the Office "I" was strengthened. Thanks to the contribution of many geographers, topographic maps for the troops on the field were realized, and enriched the General Staff monographs and the Military Maps Office.

In 1913 Cesare Battisti, the irredentist from Trentino that participated in the Great War, entered the army Intelligence in charge of patrol until July 1914.

In the years before the First World War, the Italian military Intelligence was not much structured. And the same was with the counter-Intelligence, offices in charge of the interception, and encryption.

From the early years the conflict suffered from the overlapping of tasks with other agencies (the troops reported information to the Supreme Command without passing through the Office "I").

Giovanni Giolitti devoted great attention to the civil service, both as Home Office Minister (1901-1902) and as Prime Minister (second term: 1903-1905). The assassination of King Umberto I by the anarchist Gaetano Brescia (1900) led to a new police Intelligence implementation.

Before the outbreak of the civil war, the Intelligence structure was divided in two sections, each sub-divided in two divisions: the Home Office Cabinet formed by the "Ufficio affari politici e riservati" and the "Servizio informazioni riservate", and the Public Security General Directorate with the "Ufficio riservato" and the "Servizio di guardie di città" (city guards), a body of the "polizia bassa".

\section{The First World War}

At the outbreak of the First World War, the Italian Intelligence was fragmented with no specific tasks assigned.

The military service focused almost exclusively on the troops at the front, while the police on the domestic affairs. A new office was created, the Political and Military Information Central Bureau, which updated the Prime Minister on political and military matters, both in time of peace and war. In 1917 the General Giovanni Garruccio left the seat as the "I" office commander and became the first director.

In addition to the four existing services, in 1917 due to war reasons the Central Bureau of Investigation, the UCI, was created. The new body, interconnected with the existing military Departments, had counter-Intelligence and military police tasks outside the war zones.

The UCI was commissioned to quell the growing anti-militarist propaganda (1917) and managed to dismantle in Rome, in the month of November of the same year, an enemy spy network with the arrest of several agents, an operation aimed at redeeming the Caporetto defeat.

The military Intelligence, for the first time opened to non-traditional fields, such as economics, social and political areas (the civil service traditional sectors). 
When Italy entered into the war (1915), the army General Staff (SME) information Office was transferred to the troops Supreme Command in Udine, and only a section remained in Rome. On the battle field it was organized into six sections. The third section dealt with the counter-Intelligence and the military police and was traditionally assigned to the Carabinieri Intelligence.

Despite the military Intelligence was under the direction of the "I" Office (Viviani, 1985), each Corps its own Intelligence Unit, and their reports were given directly to the Supreme Command. The operations Department ("Reparto operazioni e situazioni") had to manage information from two different sources.

The Italian military service participated with the corresponding allied Departments to the Information and the Inter-espionage Office based in Paris (an Italian Section was opened). The Navy informative activity didn't collaborate with the army. The Navy signed an agreement with the corresponding French corps, and the two bodies exchanged information.

During the war, important innovations on the technical side were introduced: aerial reconnaissance, decryption, sympathetic inks, newspaper ads.

In 1916 a reform (during the Colonel Giovanni Garruccio premiership) met up with the jurisdictional disputes on the information gathering. The Supreme Command Situation and Operations Office focused on the battle field troops, while the SME "I" Office (or "Supreme Command information office") focused exclusively on abroad and counter-Intelligence, more strategic than the ITO (Information from the Troops on the Battle field) office. From 1914, the SME commander coincided with the Supreme Commander (hence the new name of the structure).

This, in short, the new Supreme Command information structure:

- A Department commander based in Rome, in Milan and Udine;

- Three mobilized sections, namely U (Udine), M (Milan), R (Rome);

- A regional office in Milan and a branch office in Rome;

- Seventeen detached centers abroad.

The " $\mathrm{R}$ " counter-Intelligence and military police Department overlapped with the Carabinieri counter-Intelligence activities. The Department often bypassed its competence given the rather tenuous distinction between counter-espionage, and counter-espionage in the rear to the front.

As already mentioned, the Supreme Command and the ITO office were headed by the "Ufficio Situazioni ed Operazioni di Guerra". Each Army had an information office, "Centro Raccolta Informazioni Truppe Operanti" (Crito), Crito Division, Crito brigade and an ITO division Centre.

The new military Intelligence structure did not face the desired results immediately. A striking example was the Caporetto defeat (October 25 to November 12, 1917). The new director, the Colonel Odaordo Marchetti, had settled only two months before the defeat.

A psychological Unit to the demotivated troops after a severe defeat was soon created. 
The Italian Intelligence during the First World War suffered from confusion and superficiality, especially at the front. It showed the lack of an overall vision and a feasible coordination between military and civilian authorities, as well as a multiplication of Intelligence structures (De Lutiis, 1991).

\section{Conclusion}

As a conclusion, we cannot consider nowadays Italian Intelligence without a reflection on the historical process that led the Italian security agencies throughout the centuries and the pre-unification, unification, and post-unification phases and steps.

\section{References}

Colonna Vilasi, A. (2013). Storia dei servizi segreti italiani. Reggio Calabria: Città del Sole Edizioni.

De Lutiis, G. (1991). Storia dei servizi segreti in Italia. Roma: Editori Riuniti.

Pasqualini, M. G. (2006). Carte Segrete delP Intelligence Italiana. 1861-1918. Roma: Rud.

Viviani, A. (1985). Servizi segreti italiani. 1815-1985(Vol. I). 